\title{
Editorial
}

\section{Public Universities as Catalysts for Research: Rajasthan University of Health Sciences}

\author{
Sonali Sharma, ${ }^{1}$ Rajeev Gupta ${ }^{2}$ \\ ${ }^{1}$ Executive Editor, ${ }^{2}$ Editor, RUHS Journal of Health Sciences, Rajasthan University of Health Sciences, \\ Jaipur, Rajasthan, India
}

Research enables a person to collect and compile information, assess it objectively, analyse it critically and arrive at a conclusion. All these traits are important in clinical- decision- making and patient care. ${ }^{1}$ Insufficient interest in research is more a manifestation of dread due to the lack of necessary skills. ${ }^{2}$ The need of the hour is availability of opportunities for researchers wanting to promote uptake of new and evidence based tools in clinical practice. Since 2009, the Medical Council of India (MCI) has recommended publications as a criterion for promotion of medical teachers and this has now changed the role of a medical teacher to a medical teacher researcher. ${ }^{3}$ However, recent data from India show that research in medical colleges in almost non-existent and more than $50 \%$ of medical college in the country have no publication in peer-reviewed medical journals. ${ }^{4}$

The commonly perceived hurdles for doing and publishing research include a busy work schedule, inadequate knowledge of research methods, deficiency in writing skills, and lack of funding. ${ }^{5-6}$ Encouraging participation in research as a regular part of professional role fosters valuable insight into teaching and learning which can only be gained by analysing ideas. Apart from funding, qualitative and quantitative insufficiency in supervision is another important issue. ${ }^{7}$ To create impact beyond academic programmes, our university- Rajasthan University of Health Sciences (RUHS), Jaipur- is committed to capacity building of health professionals for relevant health research. The university encourages research in a way that complements the interest of society and needs of state. Implementation of active research is important for closing the knowledge-practice gap and in creating a sustainable workforce of academic researchers.

\section{Research Unit and Activities at RUHS}

Rajasthan University of Health Sciences has addressed the issue of lack of development of research at various regional colleges through creating a specific unit committed to develop ideas into research projects and to provide seed funding for pilot projects. The University also offers an atmosphere to conduct research by holding regular research methodology courses and creating a transparent research funding system. This is unique feature in the medical field in the country as there are very few similar programs to facilitate research and funding mechanisms in the country. This feature is similar research endowments available at many of the well known international universities such as Harvard, Stanford, UCLA and MIT in USA and Oxford and Cambridge in the UK.

The University has a fully functional research division comprising Advanced Research Development Unit (ARDU) supervised by an Executive Committee (EC). Both have been appointed with permission of Board of Management (BOM) to promote research within constituent and affiliated medical, dental, pharmacy and paramedical colleges. The members of ARDU and EC are dedicated to develop and guide researchers in completing a research project (outside of thesis course-work) and fulfil their intellectual ambition. Good quality medical research requires not only ideas and expertise in the chosen area of interest but also allocating funds. University provides grants to support faculty in conducting small research projects for development of innovative approaches for patient care and community based health research. To pioneer in research, RUHS has a research expenditure allocated under separate head. Research projects are screened and sponsored thereafter. A partial list of research projects approved and funded in RUHS constituent colleges (Table 1) and affiliated colleges (Table 2) in the last 3 years shows the broad spectrum of research. Apart from development and funding of the research project, other important objectives of ARDU is to monitor progress, overseeing completion of projects, preventing duplication of research and fostering collaboration with local, national and international institutes. 
Table1: Ongoing and approved research projects at constituent colleges of RUHS

\begin{tabular}{|c|c|}
\hline Name of Department & Title of Research Project \\
\hline Community & e-Health initiatives for villages in Rajasthan. \\
\hline \multirow[t]{3}{*}{ Medicine } & Effectiveness of m-Health in improving fetal outcome. \\
\hline & $\begin{array}{l}\text { Survey of prevalence of metabolic syndrome in rural population of district Jaipur and } \\
\text { evaluation of effectiveness of mHealth intervention programme (mHealth-MS) on its } \\
\text { components: A pilot study. }\end{array}$ \\
\hline & $\begin{array}{l}\text { Evaluation of gaps in management of hypertension in India: A multisite registry-based study: } \\
\text { India Heart Watch-3. }\end{array}$ \\
\hline \multirow[t]{2}{*}{ Periodontics } & $\begin{array}{l}\text { Clinical efficacy of amino bisphosphonate on periodontal disease status in post- } \\
\text { menopausal women in the state of Rajasthan: A randomized double blind placebo controlled trial }\end{array}$ \\
\hline & $\begin{array}{l}\text { A randomized clinical trial to check the efficacy of locally administered } 1.2 \% \text {. Rosuvastatin in } \\
\text { patients with chronic periodontitis. A non-surgical interventional study on Rajasthan population . }\end{array}$ \\
\hline Prosthodontics & $\begin{array}{l}\text { Development and validation of biomarkers in oral squamous cell carcinoma for regional } \\
\text { population: A pilot study. }\end{array}$ \\
\hline Dental Materials & $\begin{array}{l}\text { Evaluation and quantification of growth pattern of the stem cells taken from different } \\
\text { dental tissues in order to assess the possibility of tooth regenerating or repair. }\end{array}$ \\
\hline \multirow[t]{4}{*}{ Biochemistry } & $\begin{array}{l}\text { Influence of physical activity on inflammatory markers in patients with hypertension } \\
\text { with various gene risk-scores. }\end{array}$ \\
\hline & $\begin{array}{l}\text { Role of yoga in reducing inflammation and oxidative stress in patients of type } 2 \text { diabetes } \\
\text { mellitus. }\end{array}$ \\
\hline & $\begin{array}{l}\text { To investigate the influence of gut microbiota composition on inflammatory markers in } \\
\text { dyslipidemic subjects on statin therapy. }\end{array}$ \\
\hline & $\begin{array}{l}\text { Identification of genetic loci specific to Indian population involved in development of } \\
\text { type } 2 \text { diabetes and cardiovascular diseases using a family-based cohort design. }\end{array}$ \\
\hline Microbiology & $\begin{array}{l}\text { Detection and genotyping of human Papilloma virus from cervical samples in clinically } \\
\text { symptomatic women in Rajasthan: A multicentric study. }\end{array}$ \\
\hline \multirow[t]{3}{*}{ Physiology } & $\begin{array}{l}\text { Prevalence study of hearing loss among high risk neonates and evaluation for need of } \\
\text { neonatal hearing screening program in Rajasthan. }\end{array}$ \\
\hline & $\begin{array}{l}\text { To assess the physical fitness of school children and to determine the association of } \\
\text { muscle strength with dynamometry and cardiorespiratory fitness indirectly measured Vo } 2 \\
\text { max by the Queen's college step test. }\end{array}$ \\
\hline & $\begin{array}{l}\text { QUASI prospective comparative study on effect of yoga among prediabetics on } \\
\text { progression of cardiovascular risk factors. }\end{array}$ \\
\hline
\end{tabular}

\section{Promoting Research at RUHS}

Research is always recommended for faculty, residency programs, undergraduates which helps them in future academic fellowship. Having research projects on your curriculum vitae (CV) may help set a researcher apart from other candidates who have interested in more conventional areas of study. RUHS runs research career doctorate programmes and facilitates faculty for participation in research. The university itself has been host to many of scientific events. Workshops on research methodology and on writing skills for biomedical publications are organised with active participation of state-level faculty and medical students. The University also encourages faculty and students to publish their work to get wider recognition and wider audience through publication of an indexed quarterly journal - RUHS Journal of Health Sciences. Motto of the journal is rapid peer review and timely publication of meritorious articles and is presently in fourth year of its publication. Although, it is mandatory for postgraduate students to write a thesis/dissertation during their course, most of these researches go unnoticed. This journal publishes a yearly abstract issue to provide a platform to these PG thesis/dissertations to reach to wider audience. Research based scholarships like ICMR-STS are being proposed by university for undergraduate students of various faculties. 
Table 2: Ongoing and approved research projects at affiliated medical colleges of RUHS

\begin{tabular}{|c|c|}
\hline Name of Department & Title of Research Project \\
\hline Psychiatry & Effects of Vipasana meditation on social adaptive functioning of psychiatric patients. \\
\hline \multirow[t]{3}{*}{ Microbiology } & Anti-tuberculosis and anti-viral activity of havan smoke and havan samagri extract. \\
\hline & $\begin{array}{l}\text { New technologies for the treatment of tuberculosis: } \mathrm{pH} \text {-responsive layered nanoparticles for an } \\
\text { efficient and controlled intracellular delivery of oral antibiotics for Mycobacterium } \\
\text { tuberculosis. }\end{array}$ \\
\hline & $\begin{array}{l}\text { A cross sectional study on throat microbiome in subjects with subclinical rheumatic heart } \\
\text { disease or clinical rheumatic heart disease and comparing it with normal healthy subjects of } \\
<40 \text { years age. }\end{array}$ \\
\hline \multirow[t]{2}{*}{ Radiological Physics } & Estimation of dose reference levels (DRL) for various radiological procedures. \\
\hline & $\begin{array}{l}\text { Investigation of role of radiation-induced bystander effects in radiation toxicity during } \\
\text { radiotherapy treatment. }\end{array}$ \\
\hline \multirow[t]{2}{*}{ General Medicine } & $\begin{array}{l}\text { Elucidation of plasma concentrations of morphine, its metabolites and endorphins in cancer } \\
\text { patients and their correlation with pain. }\end{array}$ \\
\hline & $\begin{array}{l}\text { Selected genes expressing profiling and plasma levels of TGF- } \alpha \text { and IL- } 6 \text {, in chronic myeloid } \\
\text { leukemia-chronic phase (CML-CP) patients and the correlation of the same with molecular } \\
\text { response. }\end{array}$ \\
\hline \multirow[t]{2}{*}{ Pathology } & $\begin{array}{l}\text { Circulating tumor DNA as a non-invasive prognostic marker to monitor the therapy response in } \\
\text { gallbladder cancer patients. }\end{array}$ \\
\hline & $\begin{array}{l}\text { Evaluation of cell free DNA (cfDNA) as a clinical biomarker in effective management of breast } \\
\text { cancer. }\end{array}$ \\
\hline
\end{tabular}

Developing a research culture to close the research gap is an important step towards creating researchers of excellence. RUHS acts as a point of nucleation for a remarkable array of associated regional colleges with the goal to bring the researchers on forefront research excellence. The fundings can make a difference in overcoming challenges in undertaking research projects thus, improving the health and lives of people of Rajasthan state. These measures on part of university benefits to truly succeed in an academic or research oriented career. With these measures RUHS aims to be a dynamic and robust research enterprise.

\section{REFERENCES}

1. Wickramasinghe DP, Perera CS, Senarathna S, Samarasekera DN. Patterns and trends of medical student research. BMC Med Educ. 2013;13:175.

2. Rivera JA, Levine RB, Wright SM. Completing a scholarly project during residency training. Perspectives of residents who have been successful. J Gen Intern Med 2005;20:366-9.

3. Asokan N, Shaji KS. Methods to enhance capacity of medical teachers for research publications. Indian J Public Health. 2016;60:154-8.

4. Ray S, Shah I, Nundy S. The research output from Indian medical institutions between 2005 and 2014. Curr Med Res Pract. 2016;6:49-58.

5. Bavdekar SB, Tullu MS. Research publications for academic career advancement: An idea whose time has come. But is this the right way? J Postgrad Med. 2016; 62: $1-3$.

6. Bavdekar SB, Tullu MS. Success in publishing: The answer lies in training and improving research infrastructure. J Postgrad Med. 2016;62(2):139.

7. Remes V, Hellineus I, Sinisaari I. Research and medical students. Med Teach. 2000;22:164-7.

\section{Corresponding Author}

Dr Sonali Sharma, Professor and Head, Department of Biochemistry, RUHS College of Medical Sciences, Rajasthan University of Health Sciences, Jaipur, Rajasthan, India.

email: sonalisharma14@gmail.com 